\title{
Studies on the Mode of Action of Bacteriocin Produced by Lactobacillus fermentum CrT21
}

\author{
Oluwafemi Adedire ${ }^{1}$, Omowumi Adegboye ${ }^{1}$, Adebayo Osesusi ${ }^{2}$ \\ ${ }^{1}$ Federal College of Agriculture, Apata, Ibadan, Nigeria \\ ${ }^{2}$ Ekiti State University, Ado Ekiti, Nigeria
}

\begin{abstract}
Lactic acid bacteria (LAB) are very important preservative microflora involved in the fermentation of food products due to their ability to produce organic acids, bacteriocins and other bioactive antimicrobial metabolites. LAB in this study were isolated from cassava waste and retting, screened for their ability to produce bacteriocin and the bacteriocin was subsequently characterized. Lactobacillus fermentum CrT21 produced bacteriocin with crude and purified activity units of 1280 and 2560 AU/ml respectively; purification was done by ammonium sulphate precipitation and through 1, 10 and $20 \mathrm{KDa}$ ultrafiltration membranes. The bacteriocin retained its inhibitory activity over a wide range of temperature $\left(40^{\circ}-100^{\circ} \mathrm{C}\right), \mathrm{pH}(2-10)$ and in presence of metals, surfactants and enzymes (lipase and lysozyme); the activity was further characterized to cleave the peptide bond between D-glutamic acid and L-lysin along the peptide stem chain of L. fermentum CpLO8 peptidoglycan wall.
\end{abstract}

Keywords: Lactic acid bacteria, bacteriocin, activity units, Lactobacillus fermentum

\section{Introduction}

Most known Lactic acid bacteria (LAB) are non-pathogenic, low-GC containing, acid-tolerant, and generally recognized as safe (GRAS) microorganisms. They are generally grampositive, non-spore forming, cocci or rods, and produce lactic acid as the major end product of carbohydrate fermentation [1], they include the genera Lactococcus, Streptococcus, Leuconostoc, Pediococcus and Lactobacillus; however, some taxonomic submissions on LAB classification included the genera: Enterococcus, Carnobacterium, Aerococcus, Tetragenococcus, Weissella and Vagococcus [2].

Improving intestinal health through the activities of bacteriocins of dairy product associated LAB is extremely important to expand the potential application of these food products to better improve human health. Bacteriocins, including those produced by lactic acid bacteria, have been defined as ribosomally synthesized primary or modified bioactive peptides, with bactericidal or bacteriostatic effect on other (usually closely related) species [3].

LAB produce a wide range of proteinaceous bacteriocins and bacteriocin-like extracellular metabolites [4], their bactericidal mechanisms vary and many include pore formation on the cell wall of sensitive cells [5]. Bacteriocins produced by LAB strains have the potentials to provide an additional platform for controlling several food spoilage and many pathogenic microorganisms. Bacteriocins with broad spectrum activities have been reported; among these are bacteriocins, particularly from Bacillus and Pseudomonas species, with inhibitory activities against spoilage fungi of agricultural products [6]. Lactobacillus fermentum is frequently isolated from mucosal surfaces of healthy humans and fermented foods [7] and based on its probiotic properties (especially, an array of bacteriocin production), it has been characterized to have beneficial effects on the gastrointestinal tract and has also been used as an alternative treatment for urogenital infection.
So far, studies on bacteriocins have concentrated on their genetic features (coding and reading), process of production, transportation, expression, immunity, susceptibility, mode of action of individual bacteriocin on susceptible strains, as well as the identification and characterization of novel bacteriocins from microorganisms that are not previously characterized as bacteriocin producers or the establishment of new bacteriocins from known producers [8]. This current work is as such geared towards designing and establishing sensitive procedural steps to screen for and characterize bacteriocins from lactic acid bacteria and infer the results of such characterization.

\section{Materials And Methods}

\subsection{Isolation of Lactic Acid Bacteria}

Lactic acid bacteria were isolated from cassava waste and retting generated from a fabricated cassava processing machine. $20 \mathrm{~g}$ sample in each case was weighed into filtered stomacher bags and subsequently mixed with $200 \mathrm{ml}$ of presterilzed peptone water $(0.1 \% \mathrm{v} / \mathrm{v})$. The resulting mixture was blended at $280 \mathrm{rpm}$ for 5 minutes and serially diluted; $80 \mu \mathrm{L}$ of each dilution was pour-plated onto de Man, Rogosa and Sharp (MRS) agar. Plates were incubated both under aerobic and anaerobic conditions at $37^{\circ} \mathrm{C}$ for 48 hours, pure cultures were characterized through identification manuals and preserved in equal volume of MRS broth in sterile glycerol $(30 \% \mathrm{v} / \mathrm{v})$ until they were required for analysis.

\subsection{Screening and production of bacteriocin from LAB}

The agar diffusion bioassay described by Yanagida [9] was used to screen for bacteriocin producing LAB. One $\mathrm{ml}$ of each indicator cell suspension $\left(5 \times 10^{5} \mathrm{cfu} \mathrm{ml}^{-1}\right)$ was inoculated into $15 \mathrm{ml}$ of MRS soft agar maintained at $50^{\circ} \mathrm{C}$ and then poured into a petri dish. After solidification, this method was then modified by cutting three $5 \mathrm{~mm}$ diameter wells in the agar and each well was thereafter filled with 


\section{International Journal of Science and Research (IJSR) \\ ISSN (Online): 2319-7064}

Index Copernicus Value (2013): 6.14 | Impact Factor (2015): 6.391

$50 \mu 1$ of either treated or untreated cell-free supernatant (CFS) from each producer LAB isolate.

To prepare the CFS, one $\mathrm{ml}(0.5 \mathrm{McF}$ arland) of the LAB isolate was cultured overnight in $20 \mathrm{ml}$ MRS broth, cells were then removed by centrifugation at $10,000 \mathrm{~g}$ for $5 \mathrm{~min}$. The supernatant was thereafter filtered through a sterile $0.22 \mu \mathrm{m}$ syringe filter, this was then divided into three fractions; one left unadjusted, the second fraction was adjusted to $\mathrm{pH} 6.0$ with $1 \mathrm{M} \mathrm{NaOH}$ in order to neutralize the possible effects organic acids within the metabolite while the third fraction was neutralized with $1 \mathrm{M} \mathrm{NaOH}$ and then treated with $1 \mathrm{mg} \mathrm{ml}^{-1}$ of catalase at $25^{\circ} \mathrm{C}$ for $30 \mathrm{~min}$ to eliminate the possible effects of both organic acid and the antimicrobial effect of $\mathrm{H}_{2} \mathrm{O}_{2}$ respectively. These fractions were filtered and $5.0 \mu \mathrm{l}$ each of the unadjusted and the adjusted CFS aliquots were added separately to each of the bored wells. The prepared plates were replicated and incubated at $37^{\circ} \mathrm{C}$ for $24 \mathrm{~h}$. Inhibition zones were measured and scored positive if inhibition against the indicator lawn was equal to or greater than $2 \mathrm{~mm}$ [10]. However, if inhibition exists against indicator lawn from the $\mathrm{NaOH}$ and catalase adjusted metabolite well, the metabolite is scored positive for possible bacteriocin content for further characterization.

\subsection{Purification and Characterization of bacteriocin}

The first purification step of cell free bacteriocin from Lactobacillus fermentum CrT21 was done by protein precipitation with the addition of solid ammonium sulphate to $0 \%-70 \%$ saturation followed by $70 \%-90 \%$ saturation and centrifuged after storing overnight at $4^{\circ} \mathrm{C}$ [11]. The mixture was stirred for $2 \mathrm{~h}$ at $4^{\circ} \mathrm{C}$ and later centrifuged at $20,000 \mathrm{rpm}$ for $1 \mathrm{~h}\left(4^{\circ} \mathrm{C}\right)$. The centrifuged precipitates were pooled, re-suspended in of $0.05 \mathrm{M}$ potassium phosphate buffer ( $\mathrm{pH} 7.0$ ) to the initial volume of culture filtrate; the resulting solution was thereafter dialyzed against $0.05 \mathrm{M}$ potassium phosphate buffer ( $\mathrm{pH} 7.0$ ) in a tubular cellulose membrane (spectra por number four dialysis tube) for 16 hours at $4{ }^{\circ} \mathrm{C}$ for further purification. Assay of the bacteriocin activity was thereafter carried out in both the precipitate and supernatant [12].

The partially purified bacteriocin fraction collected from the ammonium sulphate precipitation procedure was then further purified through ultrafilteration technique. The Fraction was resuspended in $50 \mathrm{mM}$ potassium phosphate buffer $(1: 30 \mathrm{v} / \mathrm{v}$, $\mathrm{pH} 7.0) .1 \mathrm{ml}$ aliquot was then ultrafiltered through 1,10 and $20 \mathrm{KDa}$ molecular exclusion sizes of filtron membranes. Bacteriocin activity was determined in eluted fractions [12], while protein concentration of each purification fraction was determined by the Bradford method [13].

2.4 Effect of various chemicals, temperature, $\mathrm{pH}$ and enzymes on purified bacteriocin

To determine the effect of temperature on the activity of purified bacteriocin from L. fermentum CrT21, 400 $\mu$ l of this metabolite was exposed to various heat treatments: 40, 80, 100 and $121^{\circ} \mathrm{C}$ for 60 minutes [14], cooled to room temperature and then assayed for residual bacteriocin activity. Effect of $\mathrm{pH}$ on the partially purified bacteriocin was determined by adjusting the $\mathrm{pH}$ of the bacteriocin to 2.0 , 4.0, 6.0, 8.0 and 10 using hydrochloric acid $(\mathrm{HCl})$ and sodium hydroxide $(\mathrm{NaOH})$. The treated metabolite in each case was incubated for 60 minutes at room temperature, then neutralized and assayed for residual activity [15].

To examine the effect different enzymes on the bacteriocin, $1 \mathrm{mg} / \mathrm{mL}$ final concentration of enzymes (trypsin, lysozyme and lipase) were added, at room temperature, to the bacteriocin for 60 minutes. The effect of surfactants on the purified bacteriocin was determined by adding Triton X-100, Tween 20 and Tween 80 to the bacteriocin to a final concentration of $1 \% \quad(\mathrm{v} / \mathrm{v})$, while $0.1 \mathrm{~g} / \mathrm{mL}$ Ethylelediaminetetraacetic acid (EDTA) and Sodium dodecyl sulphate (SDS) were added at the final concentration of $10 \%(\mathrm{v} / \mathrm{v})$ [11], Urea was added at $6 \mathrm{M}$ final concentration. The effect of metal ion on bacteriocin activity was determined by adding $\mathrm{CaCl} .2 \mathrm{H}_{2} \mathrm{O}$, $\mathrm{FeSO}_{4} .6 \mathrm{H} 2 \mathrm{O}, \mathrm{MgSO}_{4} .6 \mathrm{H}_{2} \mathrm{O}, \mathrm{ZnSO}_{4} .7 \mathrm{H}_{2} \mathrm{O}$ or $\mathrm{CuSO}_{4}$ at $2 \mathrm{mM}$ final concentration [16]. Bacteriocin treatment was allowed to stay for 60 minutes before the analysis of residual activity; untreated bacteriocin was used as a positive control while treatment without bacteriocin (replacing bacteriocin with sterile distilled water in each case) was used as negative control.

\subsection{Effect of bacteriocin on purified cell wall of indicator cell}

\subsubsection{Extraction and digestion of Lactobacillus fermentum \\ CpL08 cell wall}

Lactobacillus fermentum CpL08 (0.5 McFarland) was grown overnight in MRS broth, then centrifuged at $10000 \mathrm{rpm}$ for 15 minutes to separate the cells from the growth medium and other metabolites. The collected cells were washed twice with $20 \mathrm{mM}$ phosphate buffer $(\mathrm{pH} \mathrm{7.0)}$ and resuspended in same buffer for ultrasonication, which was carried out at 20 $\mathrm{kHz}$ for 20 minutes. To remove unbroken cells, the resulting solution was heated at $95{ }^{\circ} \mathrm{C}$ for 15 minutes, followed by centrifugation at $2000 \mathrm{rpm}$ for 15 minutes. Nucleases, DNAse and RNAse (1 mg each), were added and allowed to stand at room temperature for 4 hours, $1 \mathrm{mg}$ trypsin was also added and each added enzyme was removed by centrifugation (20000 rpm for 30 minutes), the recovered cell wall was lyophilized till it is used for subsequent analysis [17]. Purified cell wall of L. fermentum CpL08 $(0.5 \mathrm{mg}$ in $10 \mathrm{mM}$ phosphate buffer, $\mathrm{pH} 7.0$ ) was added at $30 \%(\mathrm{v} / \mathrm{v})$ to 1280 AU/mL diluted purified bacteriocin of L. fermentum CrT2 1 and digestion was allowed to proceed for 14hours, while undigested cell wall was thereafter removed at $16000 \mathrm{rpm}$ for 15 minutes.

\subsubsection{Extraction of generated $\mathrm{N}$ and $\mathrm{C}$-terminal amino acids}

Eighty microliter of potassium tetraborate $\left(\mathrm{K}_{2} \mathrm{~B}_{7} \mathrm{O}_{4}\right)$ and 10 $\mu l$ fluorodinitrobenzene reagent was added to the bacteriocin digested cell wall of $L$. fermentum CpL08, this was incubated at $60{ }^{\circ} \mathrm{C}$ for 30 minutes and the resulting mixture was acidified with $50 \mu \mathrm{l}$ concentrated $\mathrm{HCl}$, the $\mathrm{N}$ dinitrophenyl (DNP) derivatives of free amino acids within the digested cell wall mixture was then extracted with ether. Residual ether was removed at $37{ }^{\circ} \mathrm{C}$ with gentle agitation and the extracted amino acids were resuspended in $0.05 \mathrm{M}$ 


\section{International Journal of Science and Research (IJSR) \\ ISSN (Online): 2319-7064 \\ Index Copernicus Value (2013): 6.14 | Impact Factor (2015): 6.391}

$\mathrm{NH}_{3}$. For liberated C-terminal amino acids, the digested cell wall of L. fermentum CpL08 was resuspended in $50 \mu \mathrm{l}$ hydrazine at $60{ }^{\circ} \mathrm{C}$ for $16 \mathrm{hrs}$, benzaldehyde $(25 \mu \mathrm{l})$ was thereafter added and mixed intermittently for $1 \mathrm{hr} .100 \mu \mathrm{l}$ of the resulting mixture was added to another $25 \mu 1$ benzaldehyde and also mixed for $1 \mathrm{hr}$; extracted C-terminal amino acid was then recovered with ether as earlier described [18]. In each case, standard amino acids (alanine, aspartic acid, glutamic acid and lysine) generally found in LAB cell wall [19] were extracted with each procedure and used as control reference for subsequent thin layer chromatography.

\subsubsection{Thin layer chromatography of amino acid samples}

To determine each free amino acid released by the bacteriocin digestion of L. fermentum CpL08 cell wall, the extracted amino acids (both standard and digested) were spotted on silica gel coated aluminum sheets of the chromatograph and developed with isopropanol at room temperature. The preparation was visualized under UV light to determine the distance traveled by each amino acid.

\section{Results and Discussion}

In all, 28 strains of several species of LAB were isolated from cassava waste and retting, they all produced inhibitory metabolites against other LAB and non-LAB isolates. Having produced extracellular metabolite inhibitory to indicator lawn from the adjusted metabolite well (with both $\mathrm{NaOH}$ and catalase), Lactobacillus fermentum CrT21 was characterized to produce bacteriocin against other LAB (Table 1), including Lactobacillus fermentum CpL08 (1280 $\mathrm{AU} / \mathrm{mL}$ ) which was selected as indicator strain for further characterization of bacteriocin produced by $L$. fermentum CrT21

\subsection{Purification of bacteriocin from L. fermentum CrT21}

Inhibitory activity was detected, after ammonium sulphate purification, only in the salt precipitate (protein content of the metabolite) and not in the supernatant. Gradual increment in specific activity of bacteriocin was recorded with the purification steps applied (Table 2). Maximum bacteriocin elution and specific activity (8533.3) was recorded with the $10 \mathrm{KDa}$ molecular exclusion pore size through ultrafiltration procedure; this might correspond with the average molecular size of the bacteriocin produced by $L$. fermentum CrT21. Increments in bacteriocin activity, achieved through precipitation and ultrafiltration procedures, have been similarly reported by Novak and Elayaraja [20; 21].

\subsection{Characterization of purified bacteriocin}

Part of the fascinating reported characteristics of bacteriocins is their ability to retain a significant fraction of their inhibitory properties over a wide range of conditions [22], bacteriocin from L. fermentum CrT21 retained all or most of its inhibitory activity (1280-640 AU/ml) at temperature range of $40-80{ }^{0} \mathrm{C}, \mathrm{pH} 2-8$ as well as in the presence of various metal ions and enzymes (Table 3 ). However, increment in activity was observed in the presence of Tween 80, Tween 20 and SDS but loss of activity was recorded at $121{ }^{\circ} \mathrm{C}$ and in the presence of Trypsin.

Table1: Antimicrobial activity of L. fermentum CrT21 bacteriocin

\begin{tabular}{|l|l|}
\hline Lactic Acid Bacteria & Activity Unit (AU/ml) \\
\hline Lactobacillus casei CrT11 & 1280 \\
\hline Lactococcus lactis Y02 & 320 \\
\hline Lactobacillus fermentum CpL08 & 1280 \\
\hline Lactobacillus plantarum CpL16 & 640 \\
\hline
\end{tabular}

\subsection{Effect of bacteriocin on purified cell wall of indicator} cell

The extracted amino acids resulting from the purified cell wall digestion of L. fermentum CpL08 by the bacteriocin of L. fermentum CrT21, run on the thin layer chromatographic sheet, showed the presence of derivatized C-terminal glutamic acid and N-terminal lysine when compared to standard amino acids (Figure 1). This indicates that the bacteriocin cleaved the peptide bond between D-glutamic acid and L-lysin along the peptide side chain of the peptidoglycan wall of L. fermentum CpL08 (Figure 2). This could lead to loss in the maintenance of cell integrity and internal turgor pressure [23], thereby depleting L. fermentum CpL08's ability to mediate interactions with both biotic and abiotic components.

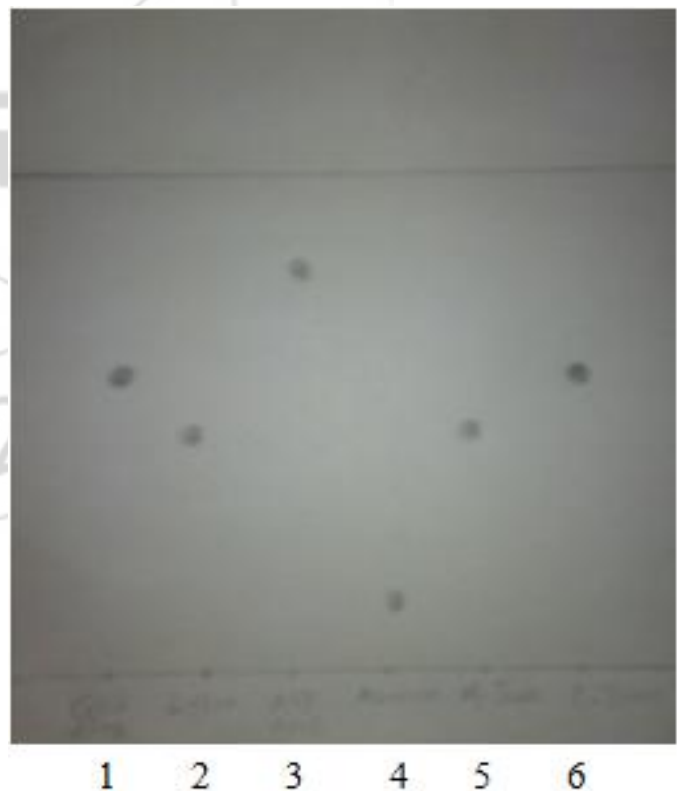

Figure 1: Thin Layer Chromatographic sheet of standard and extracted amino acids

Spots 1, 2, 3, 4, 5 and 6 are standard Glutamic acid, standard Lysine, standard Aspartic acid, standard Alanine, extracted N-terminal lysine and extracted C-terminal Glutamic acid respectively. 
International Journal of Science and Research (IJSR)

ISSN (Online): 2319-7064

Index Copernicus Value (2013): 6.14 | Impact Factor (2015): 6.391

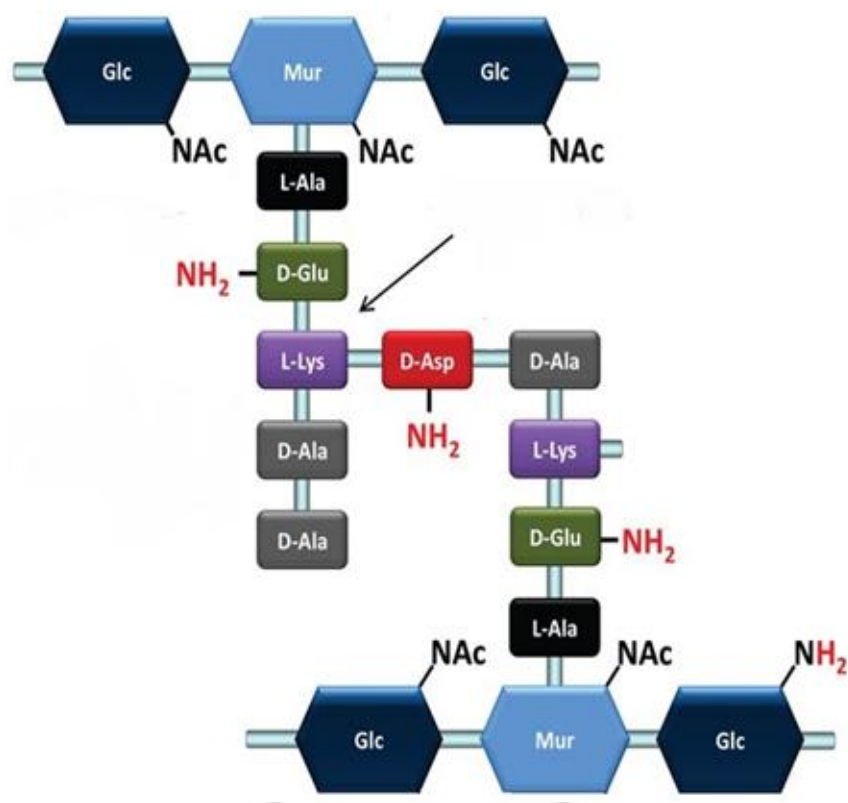

Figure 2: Cleaving site of L. fermentum CrT21 bacteriocin on L. fermentum CpL08 cell wall. Adapted: Chapot-Chartier and Kulakauskas (2014).

Table 2: Purification of bacteriocin from L. fermentum CrT21

\begin{tabular}{|c|c|c|c|c|c|c|c|}
\hline \multirow[t]{2}{*}{ Purification step } & \multirow{2}{*}{$\begin{array}{l}\text { Volume } \\
\text { (ml) }\end{array}$} & \multirow{2}{*}{$\begin{array}{c}\text { Activity } \\
\text { Unit } \\
(\mathrm{AU} / \mathrm{ml})\end{array}$} & \multirow{2}{*}{$\begin{array}{c}\begin{array}{c}\text { Total } \\
\text { activity }\end{array} \\
(\mathrm{AU} / \mathrm{ml}) \\
\end{array}$} & \multirow{2}{*}{$\begin{array}{c}\text { Protein } \\
(\mathrm{mg} / \mathrm{ml})\end{array}$} & \multirow{2}{*}{$\begin{array}{l}\text { Specific } \\
\text { activity }\end{array}$} & Purification & \multirow[t]{2}{*}{ Recovery (\%) } \\
\hline & & & & & & fold & \\
\hline Crude & 500 & 1280 & 640000 & 1.5 & 853.3 & 1 & 100 \\
\hline Ammonium sulphate & 30 & 2560 & 76800 & 1.2 & 2133.3 & 2.5 & 80 \\
\hline $1 \mathrm{KDa}^{*}$ & 5 & 320 & 1600 & 0.06 & 5333.3 & 6.3 & 4 \\
\hline $10 \mathrm{KDa}^{*}$ & 4 & 2560 & 10240 & 0.3 & 8533.3 & 10 & 20 \\
\hline $20 \mathrm{KDa}^{*}$ & 6 & 1280 & 7680 & 0.5 & 2560 & 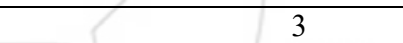 & 33.3 \\
\hline
\end{tabular}

${ }^{*}$ Each filtration was done with a $10 \mathrm{ml}$ batch from the ammonium sulphate precipitate solution.

Activity unit $=$ Reciprocal of the highest bacteriocin dilution with at least $2 \mathrm{~mm}$ inhibition diameter.
Total activity $=$ Activity $\mathrm{x}$ volume; Specific activity $=$ Activity unit/protein content; Purification fold=Specific activity/crude specific activity; Recovery=Protein concentration /Crude protein concentration.

Table 3: Effect of various treatments on the inhibitory activity of $L$. fermentum CrT21 bacteriocin

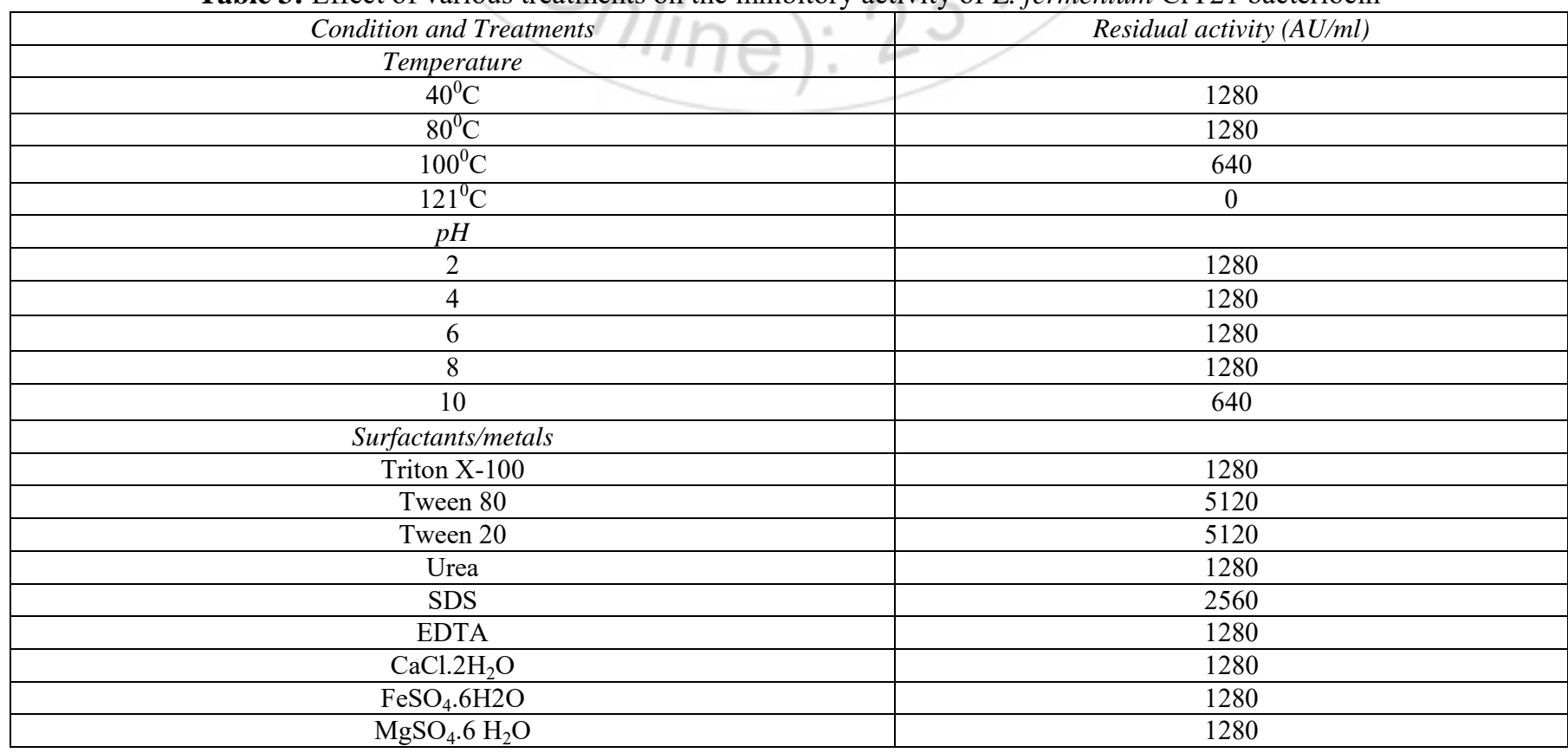


International Journal of Science and Research (IJSR)

ISSN (Online): 2319-7064

Index Copernicus Value (2013): 6.14 | Impact Factor (2015): 6.391

\begin{tabular}{|c|c|}
\hline $\mathrm{ZnSO}_{4} \cdot 7 \mathrm{H}_{2} \mathrm{O}$ & 1280 \\
\hline $\mathrm{CuSO}_{4}$ & 1280 \\
\hline Enzymes & 0 \\
\hline Trypsin & 1280 \\
\hline Lipase & 1280 \\
\hline lysozyme & 1280 \\
\hline
\end{tabular}

\section{References}

[1] Fan, Lihua and Song, Jun (2013). Antimicrobial microbes-bacteriocin producing lactic acid bacteria. In: Méndez-Vilas, A. eds. Microbial pathogens and strategies for combating them: science, technology and education. Formatex, Pg: 899-109

[2] Axelsson, L. (1998). Lactic acid bacteria: classification and physiology. In: Salminen S, von Wright A, eds. Lactic acid bacteria, microbiology and functional aspects. New York: Marcel Dekker Inc, Pg.: 1-73

[3] Adebayo, F. A., Afolabi, O. R. and Akintokun, A. K. (2014). Antimicrobial Properties of Purified Bacteriocins Produced from Lactobacillus casei and Lactobacillus fermentum against Selected Pathogenic Microorganisms, British Journal of Medicine and Medical Research 4(18): 3415-3431

[4] Musikasang, H., Sohsomboon, N., Tani, A. and Maneerat, S. (2012). Bacteriocin-producing lactic acid bacteria as a probiotic potential from Thai indigenous chickens. Czech J. Anim. Sci., 57 (3): 137-149.

[5] Todorov, S. D., Rachman, C., Fourrier, A., Dicks, L. M. T., van Reenen, C. A., Prevost, H. and Dousset, X. (2011): Characterization of a bacteriocin produced by Lactobacillus sakei R1333 isolated from smoked salmon. Anaerobe, 17, 23-31

[6] Adedire O. M., Ogundipe W. F., Olaoye' S. O., Farinu, A. O., Fajobi, A. K., Adegboye, O. and Pitan, A. A. (2015). Antifungal properties of bacteriocin-like extracellular metabolites (BLEMS) produced by bacteria on fungi species associated with some quality protein maize varieties. Proceeding of the $49^{\text {th }}$ Annual Conference of the Agricultural Society of Nigeria (ASN), pg.: 494-497

[7] Klein, G. (2011). Antibiotic Resistance and Molecular Characterization of Probiotic and Clinical Lactobacillus Strains in Relation to Safety Aspects of Probiotics. Foodborne Pathogens and Disease, 8(2):267-280.

[8] Field, D., Cotter, P. D., Hill, C. and Ross, R. P. (2007). Bacteriocin biosynthesis, structure and function. In: Riley, M. A. and Osnat, G., eds. Research and applications in bacteriocins. Horizon Bioscience, Cromwell Press. UK. Pg. 5-42.

[9] Yanagida, F., Chen, Y., Onda, T and Shinohara, T. 2005. Durancin L28-1A, a new bacteriocin from Enterococcus durans L28-1, isolated from soil. Letters in Applied Microbiology. 40: 430-435

[10] Herreros, M. A., Sandoval, H., González, L., Castro, J. M., Fresno, J. M., Tornadijo, M. E. (2005). Antimicrobial activity and antibiotic resistance of lactic acid bacteria isolated from Armada cheese (a Spanish goats' milk cheese). Food Microbiol 22:455-459

[11] Ogunbanwo, S. T., Sanni, A. I. and Onilude, A. A. 2003. Characterization of bacteriocin produced by Lactobacillus plantarum F1 and Lactobacillus brevis OG1. African Journal of Biotechnology 2 (8):219-227
[12] Jimenez-Diaz, R., Rios-sanchez, R. M., Desmazeaud, M., Ruiz-Barba, J. L. and Piard, J. C. (1993). Plantaricins S and T. Two New bacteriocins produced by Lactobacillus plantarum LPC 10 isolated from a green olive fermentation. Applied and Environmental Microbiology 59(5):1416-1424

[13] Bradford, M. B. (1976). A rapid and sensitive method for the quantitation of microgram quantities of protein, utilizing the principle of protein-dye binding. Anal. Biochem. 72:248.

[14] Ten Brink B, Minekus M, Vander Vossen JMBM, Leer RJ, Huis JHJ (1994). Antimicrobial activity of lactobacilli: preliminary characterization and optimisation of production of acidocin B., a novel bacteriocin produced by L. acidophilus M46. J. Appl. Bacteriol. 77:140-148

[15] Joseph, B., Dhas, B., Hena, V. and Raj, J. 2003. Bacteriocin from Bacillus subtilis as a novel drug against diabetic foot ulcer bacterial pathogens. Asian Pacific Journal of Tropical Biomedicine 3(12): 942-946

[16] Adedire Oluwafemi, Ogundipe Wuraola and Farinu Adekunle (2013). Studies on Crude Thermostable Amylase Produced by Bacillus Spp. Isolated from Starch Waste. International Journal of Science and Research, 2(4): 396-400

[17] Ghuysen, J. M., Tipper, D. J. and Strominger, J. L. (1966). Enzymes that degrade bacterial cell walls. Methods in Enzymology. 176: 7335-7344

[18] Beukes, M., Bierbaum, G., Sahl, H. G. and Hastings, J. W. (2000). Purification and partial characterization of murein hydrolase, millericin B, produced by Streptococcus milleri NMSCC 061. Applied and Environmental Microbiology, 66: 23-28

[19] Chapot-chartier, M. P. (2014). Interactions of the cellwall glycopolymers of lactic acid bacteria with their bacteriophages. Front. Microbial. 5: 236 . doi: 10.3389/fmicb. 2014.00236

[20] Novak, J., Caufield, P. W. and Miller, E. J. (1994). Isolation and Biochemical Characterization of a Novel Lantibiotic Mutacin from Streptococcus mutans, Journal of Bacteriology, 176 (14): 4316-4320

[21] Elayaraja, S., Annamalai, N. and Balasubramanian, T. (2014). Production, purification and characterization of bacteriocin from Lactobacillus murinus AU06 and its broad antibacterial spectrum. Asian Pacific Journal of Tropical Biomedicine, 4: S305-S311

[22] Sehar A. N. and Sheikh A. R. 2013. Isolation, production and characterization of bacteriocins produced by strains from indigenous environments. Pakistan Journal Botany 45(1): 261-267

[23] Marie-Pierre Chapot-Chartier, Saulius Kulakauskas (2014). Cell wall structure and function in lactic acid bacteria. Microb. Cell Fact. 13(1): S9. doi: 10.1186/14752859-13-S1-S9 